\title{
Opini dan Analisis Program Layanan Informasi di Perpustakaan dengan Metode Jarak Jauh (Studi Kasus Layanan Informasi Menggunakan Aplikasi Imobile Ipusnas)
}

\author{
Verry Mardiyanto \\ Program Pascasarjana, Universitas Islam Negeri Sunan Kalijaga \\ Email : vmardiyanto@gmail.com
}

\begin{abstract}
This study discusses about opinion and analysis of information service program in library using online method, (a case study of information service using Ipusnas Imobile Application). Qualitative descriptive approach was used in this study, and observation to iPusnas application directly was conducted for data gathering. We tried to answer how online library information service using iPusnas application was utilized, how the process flow of information service is, and what advantage and disadvantage iPusnas application has as our research problems. We found that this application is applicable to all people in general, whether they are old, young or have little capability in using the application as long as they have understood information technology. Moreover, this application can encourage millennial generation's reading interest as they spend most of their time in using information technology devices. This application is still in startup form and need to be developed more in its loading process, features, book collection, and bug improvement to support digital library.
\end{abstract}

Key Words: Digital Library, iPusnas Application, Online Library and National Library.

\begin{abstract}
Abstrak
Tulisan ini membahas mengenai opini dan analisis program layanan informasi di perpustakaan dengan metode jarak jauh, (studi kasus layanan informasi menggunakan aplikasi imobile ipusnas). Metodelogi yang digunakan adalah dengan pendekatan deskriptif kualitatif dan menggunakan pengumpulan data berupa observasi menggunakan aplikasi iPusnas secara langsung. Rumusan masalah yang diajukan adalah berupa pemanfaatan dari layanan informasi perpustakaan dengan metode jarak jauh, kasus pada pemanfaatan aplikasi iPusnas. Selanjutnya mengetahui alur proses layanan informasi di dalam aplikasi iPusnas dan kelebihan dan kekurangan yang ada di aplikasi iPusnas. Hasil yang didapatkan adalah aplikasi ini cocok untuk kalangan masyarakat pada umumnya, sehingga dapat digunakan diberbagai
\end{abstract}


umur dan orang awam sekaligus, asalkan orang tersebut sudah memahami teknologi informasi. Kemudian aplikasi ini berguna untuk menigkatkan minat baca generasi milenial yang saat ini menghabiskan aktifitasnya dengan menggunakan perangkat teknologi informasi. Ipusnas ini mendukung perpustakaan digital yang berupa start up aplikasi untuk dikembangkan ke arah yang lebih baik lagi, baik itu proses loading, fitur, koleksi buku dan perbaikan bug yang ada.

Kata Kunci : Perpustakaan Digital, Aplikasi iPusnas, Perpustakaan Jarak Jauh dan Perpustakaan Nasional.

\section{A. PENDAHULUAN}

Dewasa ini perkembangan teknologi menjadikan segala hal yang berkaitan dengan layanan menjadi lebih mudah. Salah satu layanan yang dimaksud adalah layanan dalam bidang perpustakaan. Layanan dalam bidang perpustakaan saat ini sudah melibatkan teknologi informasi dalam pencariannya, termasuk dalam sistem informasi perpustakaan seperti sistem pemantauan, sistem pengelolaan dan sistem temu kembali informasi. Aplikasi-aplikasi sistem perpustakaan saat ini adalah seperti Slims dan Inslite. Kedua sistem tersebut menunjang pengelolaan baik dari segi pengelola dan pengguna perpustakaan. Pengelola dapat dengan mudah memanfaatkan sistem tersebut untuk membantu pekerjaan dan pengguna merasakan hasil pekerjaan tersebut dalam melakukan pencarian informasi koleksi di perpustakaan dengan hanya sentuhan klik saja, pengguna sudah dapat mengetahui informasi yang di cari.

Teknologi memudahkan pengguna dan pengelola, artinya teknologi hadir untuk memudahkan pengelola dalam melakukan input dan proses suatu layanan, kemudian output tersebut menjadi hasil dari layanan yang berguna bagi pengguna. Jika diandaikan dalam bidang perpustakaan maka konsepsi manajemen dalam konteks input - proses - output adalah suatu rangkaian proses untuk membuat suatu layanan agar berjalan secara sistematis. Hadirnya teknologi ini adalah membantu bagian-bagian tersebut agar dapat memudahkan pengeloal dan pengguna dalam bidang layanan. Misalkan dalam bagian input, maka pengelola perpustakaan meberikan sentuhan teknologi terkait pada penambahan data koleksi buku, penambahan anggota dan penambahan informasi terkai layanan perpustakaan. Selanjutnya adalah bagian proses, maka pengelola memberikan kategori sentuhan jangka waktu pinjam, mekanisme denda dan prosedur penagihan. Kemudian pada luaran yang dirasakan oleh pengguna perpustakaan adalah dalam konteks mendapatkan informasi yang akurat terkait permasalahan yang ada, artinya 
pengguna mencari informasi di sistem perpustakaan mengenai permasalahannya, kemudian sistem perpustakaan memberikan solusi seperti ketersedian koleksi dan informasi tempat simpannya. Konsep manjemen tersebut adalah diandaikan jika menggunakan sistem aplikasi perpustakaan yang sudah terkoneksi dengan internet. Jadi pengelola dapat memantau dari jalur akses yang tersedia dengan koneksitas sistem internet dengan aplikasi perpustakaan, sedangkan pengguna/pengunjung perpustakaan dapat mencari informasi didalam sistem perpustakaan dengan aplikasi perpustakaan yang terkoneksi internet dimana saja dan kapan saja juga, tergantung dengan perangkat dan layanan internet yang tersedia di area pengelola dan pengguna berada. Artinya sistem perpustakaan dapat memberikan manfaat kepada pengelola dan pengguna perpustakaan dalam jaringan internet saat mereka mengakses aplikasi perpustakaan tersebut.

Program layanan informasi yang ada di perpustakaan saat ini sudah menunjukkan geliat keberadaanya. Hal ini dapat dilihat dari banyaknya perpustakaan yang menggunakan aplikasi sistem informasi perpustakaan yang saat ini sudah mengudara, seperti website dengan domain opac, digilib atau perpustakaan yang diikuti nama lembaga utama perpustakaan bernaung. Jika dilihat pada masa kini, masa digital native atau era digital, maka perpustakaan sudah saatnya menjadi perpustakaan digital atau perpustakaan hibrida. Perpustakaan digital mengedepankan titik temu dengan bantuan teknologi informasi, dalam hal ini adalah pengelola dengan memanfaatkan aplikasi sistem informasi perpustakaan dan pengguna menikmati layanan informasi tersebut dengan fitur pencarian informasi yang ada.

Aplikasi pelayanan informasi di perpustakaan yang saat ini ada adalah mendukung pembelajaran jarak jauh. Metode online learning saat ini menjadi banyak peminatnya, di kala pengguna online learning membutuhkan informasi tanpa perlu pergi ke perpustakaan. Maka online learning ini menjadi solusi untuk mengatasi masalah tersebut. Jika dilihat dari data yang dimuat dalam edukasi.kompas.com (05/05/2015) dijelaskan bahwa memang, saat ini belum semua perguruan tinggi memiliki perpustakaan digital. Salah satu yang sudah menerapkannya adalah Universitas Bina Nusantara (Binus University). Dengan metode Binus Online Learning, mahasiswa dapat mengakses perpustakaan digital sebagai fasilitas pembelajaran. Pada dasarnya perkuliahan dengan sistem online memang menuntut mahasiswa untuk belajar lebih mandiri. Oleh karena itu, tambahan fasilitas perpustakaan digital akan memudahkan mahasiswa yang membutuhkan referensi buku. "Perkuliahan dengan metode online learning tentu mendorong mahasiswa untuk self learning," ungkap Deputi Direktur Binus Online Learning, Agus 
Putranto. Masih tergolong baru, lanjut Agus, perpustakaan digital di Binus University masih bersifat hybrid atau campuran. Artinya, perpustakaan berawal dari perpustakaan tradisional, kemudian berkembang menggunakan jaringan komputer atau web. Koleksi perpustakaan juga terbagi menjadi dua, sebagian sudah digital tapi koleksi fisik pun masih tersedia. "Melalui perpustakaan digital ini metode pembelajaran online lebih maksimal. Mahasiswa tak perlu datang ke kampus kalau ingin mencari referensi pembelajaran. Buku-buku penunjang perkuliahan yang sudah berformat $e$ book bisa diunduh dengan mudah dan cepat," ujar Agus. Melihat penggunaan online learning pada Binus tersebut maka dapat dikatakan perpustakaan digital yang berawal dari perpustakaan tradisional, kemudian bertransformasi menajdi perpustakaan hibrida lalu terakhir bertransformasi menjadi perpustakaan digital ini dapat mendukung pembelajran jarak jauh atau dengan istilah online learning.

Tidak hanya pada ruang lingkup perguruan tinggi saja, terdapat kontribusi dari perpustakaan digital. Akan tetapi, perpustakaan digital juga merambah pada ruang lingkup masyarakat. Masyarakat ini adalah masyarakat pada umumnya yang menggunakan akses perpustakaan untuk menyelesaikan permasalahannya. Seperti dalam data yang ditampilkan oleh news.detik.com berikut ini mengenai "Desa di Kaki Gunung Ijen ini Dilengkapi Perpustakaan Digital". Desa Tamansari, Kecamatan Licin yang dinobatkan sebagai salah satu desa 'Smart Kampung' terus menujukkan perkembangannya. Tak hanya ada kemajuan tentang pelayanan yang sudah berbasis IT, pelayanan dan penambahan fasilitas juga dilakukan. Saat ini, desa yang tepat berada di kaki Gunung Ijen ini, dilengkapi dengan fasilitas QBaca atau Pustaka Digital. Fasilitas QBaca itu merupakan bentuk dukungan dari PT Telkom Indonesia untuk Desa Tamansari. Hal ini juga sebagai bentuk komitmen mereka di bidang pendidikan untuk meningkatkan kecerdasan bangsa melalui membaca. Fasilitas ini, kata dia, adalah perpustakaan berbasis online yang berisi ribuan buku yang dapat diakses secara gratis oleh warga. Ada kurang lebih 20 ribu buku tersedia mulai dari buku pendidikan sekolah tingkat TK hingga jenjang SMA. Sementara buku-buku tersebut juga telah sesuai dengan kurikulum yang diadopsi oleh Kementrian Pendidikan. "QBaca juga dilengkapi dengan buku ilmu pengetahuan, buku cerita maupun buku inspiratif lainnya," tambahnya. Sementara itu, Kepala Desa Tamansari, Rizal Saputra mengatakan, adanya fasilitas tambahan ini tentunya sangat bermanfaat bagi masyarakat sekitar. Ini juga akan menambah referensi bagi pendidikan yang ada di Desa Tamansari. "Kita sebelumnya sudah punya pojok baca manual untuk warga, tapi dengan Pustaka Digital ini tentunya lebih memudahkan lagi bagi masyarakat. Informasi-informasi yang dirasa perlu oleh teman-teman 
pendidikan maupun siswa jadi semakin bisa terpenuhi," terang Kepala Desa Tamansari, Kecamatan Licin, Rizal Syahputra.

Fasilitas Qbaca yang menjadi brand dari perpustakana digital di desa Tamansari ini merupakan hasil dari program CSR. Dari prorgam tersebut dapat diambil manfaat bagi masyarakat desa tamansari dan sekitarnya. Selain dapat mencerdaskan masyarakat, fasilitas ini juga sebagai tanda bahwa teknologi informasi dapat dimanfaatkan perpustakana yang dahulu hanya sebagai pojok baca dan saat ini sudah mengalami transformasi dari tradisional ke modern. Pada program Qbaca ini adalah masih dalam tahapan perpustakaan campuran, yang masih menggunakan perpustakaan tradisional sebagai sumber utama. Perlu diketahui bahwa pada masyarakat desa, tidak semuanya menguasai teknologi informasi. Oleh karena itu, perpustakaan pojok baca tetap dipertahankan, dan dihadrikan program perpustakaan digital "Qbaca" untuk mengakomodir pengguna yang ingin melihat informasi tanpa perlu datang ke pojok baca.

Program layanan informasi perpustakaan dengan metode jarak jauh. Sebagai kasus yang diangkat adalah penggunaan aplikasi Ipusnas. Aplikasi Ipusnas adalah aplikasi keluaran Perpustakaan Nasional yang mengakomodir pengguna pada layanan penyediaan informasi berupa koleksi buku. Aplikasi ini dapat berjalan pada sistem operasi windows, iphone dan android. Sistem operasi android dan iphone ini memungkinkan pengguna layanan menggunakan smartphone sebagai media alat baca. Pada sistem operasi windows, pengguna dapat memanfaatkan komputer sebagai media pembacanya. Pada dasarnya program Ipusnas ini hadir untuk mempermudah pengguna perpustakaan yaitu masyarakat Indonesia dalam menikmati layanan perpustakaan secara lebih dekat dan memperkenalkan perpustakana ke kalangan era digital saat ini. Bagaimana opini dan analisis program layanan informasi perpustakaan dengan metode jarak jauh dengan kasus pada program aplikasi Ipusnas?

\section{Rumusan Permasalahan}

1. Bagaimana pemanfaatan program layanan informasi perpustakaan dengan metode jarak jauh?

2. Bagaimana proses layanan informasi di dalam aplikasi Ipusnas?

3. Apa saja kelebihan dan kekurangan di aplikasi Ipusnas?

\section{Tujuan}

1. Menganlisis pemanfaatan program layanan informasi perpustakaan dengan metode jarak jauh. 
2. Mengetahui dan menjabarkan proses layanan informasi di dalam aplikasi Ipusnas.

3. Mendeskripsikan kelebihan dan kekurangan di aplikasi Ipusnas.

\section{Metodelogi}

Metodelogi yang digunakan dalam tulisan ini adalah dengan pendekatan kaulitatif deskriptif. Menurut Moleong (2005) menjelaskan bahwa peneltiian deskriptif adalah penelitian yang menghasilkan prosedur analisis yang dimana dalam penelitian ini tidak menggunakan prosedur analisis statistik serta memandang suatu upaya membangun pandangan subjek penelitian yang rinci, dengan dibentuk dengan kata-kata dan gambaran holistik. Metode pengumpulan data menggunakan observasi yaitu melalui aplikasi Ipusnas berbasis sistem operasi windows. Metode kualitatif deskriptif ini menjabarkan analisis dari program layanan informasi perpustakaan dengan metode jarak jauh yaitu dengan menjabarkan layanan yang ada dalam aplikasi Ipusnas. Pemanfaatan ini adalah dengan mencoba dan menggunakan layanan yang disediakan oleh aplikasi Ipusnas. Dari cara tersebut juga dapat diambil pendeskripsian kelebihan dan kekurangan yang ada pada layanan di aplikasi Ipusnas.

\section{Kerangka Pemikiran}

\section{Layanan Informasi di Perpustakaan}

Ada banyak layanan informasi yang ada di perpustakaan. Layanan informasi ini menyasar pada perpustakaan tradisional dan perpustakaan digital. Jika dilihat pada layanan informasi saat ini di perpustakaan maka layanan tradisiona menyasar pada pengguna yang datang berkunjung ke perpustakaan dengan kehadiran fisik dan buku fisik yang tertata rapi di rak perpustakaan. Namun berbeda pada layanan informasi pada perpustakaan digital yang memberikan layanan informasi tidak berupa tatap muka secara langsung, melainkan dengan media digital seperti komputer, laptop dan smartphone yang terkoneksi dengan internet. Kehadiran layanan informasi digital ini semakn lama akan menggantikan layanan informasi tradisional, sehingga perpustakaan zaman sekarang melakukan inovasi layanan informasi berupa layanan informasi digtal di perpustakaan.

Menurut Arlinah I.R (2010) Layanan informasi di bagi ke dalam beberapa jenis layanan, yaitu :

a. Layanan Sirkulasi

b. Layanan Koleksi Tandon/Khusus

c. Layanan Koleksi Pandang Dengar 
d. Layanan Referensi

e. Promosi dan Pameran Perpustakaan

f. Layanan Bimbingan / Pendidikan Pengguna

g. Layanan Penyebaran Informasi Mutakhir

h. Jasa Penelusuran Literatur

i. Layanan Pinjam Antar Perpustakaan

j. Layanan Kepada Masyarakat

Arlinah juga menjelaskan mengenai evaluasi layanan informasi di perpustakaan. Evaluasi ini bergn untuk mengukur keberhasilan layanan informasi yang diterima oleh pengguna dengan instrumen penelitian yang dilakukan. Arlinah (2010) juga menjelaskan mengenai evaluasi yang dapat dilaksanakan untuk bermacam-macam tujuan antara lain:

a. Mengetahui sampai dimana perkembangan layanan

b. Mencari cara-cara yang lebih tepat untuk dapat mengembangkan lebih jauh

c. Untuk menentukan kebutuhan diadakannya perubahan tujuan dari layanan

Layanan informasi di perpustakaan selain menyasar kepada pengguna yang membutuhkan langsung di perpustakaan juga menyasar pada pengguna dengan kriteria pengguna digital. Dalam hal ini adalah pengguna yang memanfaatkan layanan informasi secara jarak jauh. Adapun bagi pengguna yang menginginkan layanan ini dapat merujuk pada website perpustakaan dengan cara mengakses website, permintaan informasi lewat email atau fax, kemudian dengan menghubungi perpustakaan secara langsung menggunakan telepon. Metode layanan informasi jarak jauh ini sudah mulai berkembang dan akan terus berkembang mengikuti perkembangan zaman. Oleh karena itu perpustakaan akan berinovasi untuk menyediakan layanan informasi digital di dalam konsep perpustakaan modern.

\section{Perpustakaan Digital}

Istilah perpustakaan digital berawal dari tahun 1994 yang dimulai dengan pembentukan DLI. Hal ini sesuai dengan perkembangan permulaan internet pada tahun tersebut, yang mulai berkembang mengikuti seluruh aspek kehidupan yang ada. Istilah dan konsep serta aplikasi yang nyata berawal dari penelitian dan pengembangan keilmuan perpustakaan yang hakikatnya untuk mengikuti perkembangan teknologi informasi. Selain itu juga perpustakaan digital menandakan sebagai awal transformasi perpustakaan dari perpustakaan berjenis tekstual dengan administrasi yang 
masih manual bertranformasi secara digital dengan lebih dikenal sebagai perpustakaan digital.

Perpustakaan digital merupakan sebuah sistem yang memiliki berbagai layanan dan obyek informasi yang mendukung akses obyek informasi tesebut melalui perangkat digital (Sismanto, 2008). Lesk dalam Pendit (2007) memandang perpustakaan digital secara sangat umum sebagai mata-mata kumpulan informasi digital yang tertata. Menurut Arms dalam Pendit (2000) memperluas sedikitnya dengan menambahkan bahwa koleksi tersebut disediakan sebagai jasa dengan memanfaatkan jaringan informasi. Selain istilah perpustakaan digital (Digital Library) terdapat juga istilah lain seperti Electronic Library, Virtual Library, Cyber Library, dan lain sebagainya dimana semua itu memiliki makna yang sama yaitu perpustakaan yang memiliki koleksi dalam bentuk digital dan dapat diakses oleh para pengguna dimanapun dan kapanpun. Komponen perpustakaan digital yang berawal dari sistem penunjang sepertihalnya metadata ini berkembang dalam desakan pengguna dan perkembangan zaman untuk dapat melayani pengguna dan memeudahkan pengelola dalam mengorganisasi perpustakaan agar lebih baik lagi. Secara keseluruhan koleksi yang berbentuk digital dengan berbagai format dokumen dapat dikases dengan palikasi program dalam bawaan sebuah produk sistem perpustakaan.

Menurut Gatot (2009) menjelaskan mengenai perbedaan "perpustakaan biasa" dengan "perpustakaan digital" terlihat pada keberadaan koleksi. Koleksi digital tidak harus berada di sebuah tempat fisik, sedangkan koleksi biasa terletak pada sebuah tempat yang menetap, yaitu perpustakaan. Perbedaan kedua terlihat dari konsepnya. Konsep perpustakaan digital identik dengan internet atau komputer, sedangkan konsep perpustakaan biasa adalah buku-buku yang terletak pada suatu tempat. Perbedaan ketiga, perpustakaan digital bisa dinikmati pengguna dimana saja dan kapan saja, sedangkan pada perpustakaan biasa pengguna menikmati di perpustakaan dengan jam-jam yang telah diatur oleh kebijakan organisasi perpustakaan.

Menurut Pendit (2008), istilah perpustakaan digital adalah terjemahan langsung dari 'digital libraries', sebuah istilah yang lahir dan berkembang di Amerika Serikat dan menyebar secara cepat ke seluruh dunia. Digital libraries yang membawa pengaruh yang kuat dalam struktur sosial di masyarakat Amerika dengan kata "digital" menandakan secara lini kehidupan berdampak pada pola perilaku masyarakat yang berubah dalam kriteria perilaku yang berhubungan dengan digital. Karena lahir di Amerika Serikat dengan pola konsumsi masyarakat yang maju dan selalu berkembang maka menyebar luas ke seluruh penjuru dunia. Dengan kata digital yang 
berkembang pesat dengan tambahan perangkat digital yang ada maka perpustakaan digital ada, tanpa harus didesak dari dalam, namun desakan dari luar yaitu perkembangan perilaku masyarakat yang menginginkan digital sebagai salah satu cara untuk tetap terhubung ke dunia luar mesikupan masyarakat tidak sedang di area tersebut.

Perpustakaan digital sendiri dapat disimpulkan bahwa perpustakaan digital adalah perpustakaan yang murni koleksi buku sudah berbentuk digital atau e-book. Sistem yang digunakan sudah lancar dan sedikit bug, kemudian tidak memiliki perpustakaan fisik, melainkan hanya berbentuk server. Oleh karena itu, perpustakaan digital dapat diatur oleh pengelola perpustakaan, dalam hal ini adalah pustakawan dimanapun berada dan kapan pun. Sehingga yang dinamakan perpustakaan digital adalah koleksi yang disediakan benarbenar berupa dgital dan dapat dipinjamkan dengan media digital yaitu smartphone, komputer atau laptop. Pengguna perpustakaan tidak lagi perlu datang ke perpustakaan. Hanya dengan berdiam diri di rumah atau sedang dalam kendaraan sudah dapat mengakses perpustakaan digital dengan tablet bawaannya. Perpustakaan yang ada saat ini adalah perpustakaan hibria yaitu perpustakaan campuran antara tradisional dan digtal, namun dengan perkembangan teknologi informasi yang semakin cepat, maka tidak lama lagi akan ada perpustakaan yang benar-benar berupa perpustakaan digital. Perpustakaan yang hanya berupa server saja. Semua orang dapat berkontribusi di dalamnya dan mengakses di dalamnya tanpa perlu batasanbatasan yang ada seperti di perpustakaan saat ini.

\section{Konsep Perpustakaan Jarak Jauh}

Ide perpustakaan jarak jauh tidak lain adalah pada hasil dari kebutuhan pengguna yang semakin hari semakin tinggi akan penggunaan teknologi informasi. Secara saat ini bahwa teknologi informasi tidak mengenal waktu dan tempat. Oleh karena itu, perpustakaan berinovasi menciptakan perpustakaan jarak jauh. Sebagai contoh adalah perpustakaan Universitas Terbuka yang mempergunakan konsep perpustakaan jarak jauh. Hal utama adalah dengan menggunakan sistem penddikan pembelajaran jarak jauh (PPJJ). Tidak hanya pengajaran saja, melainkan perpustakaan juga diupayakan untuk mengikuti pelayanan yang diselenggarakan oleh pengelola dengan nama sebagai konsep perpustakaan jarak jauh atau perpustakaan yang berhubungan dengan pengguna dengan bantuan teknologi informasi, dalam hal ini adalah sistem perpustakaan yang terstuktur dan memudahkan.

Menurut Robinson (2004) dalam Ristiyono (2011) yang termasuk kategori perpustakaan pendidikan terbuka jarak jauh, adalah sejak 
perpustakaan ikut menangani pendidikan jarak jauh, baik melalui kursus tertulis, telekonferensi dan kelas-kelas yang diadakan luar kampus, perpustakaan universitas telah memperluas layanannya dengan mengirimkan bahan-bahan (atau fotokopi bahan-bahan) melalui pos kepada mahasiswa pendidikan jarak jauh.. Model jarak jauh yang diterapkan dalam konsep perpustakaan jarak jauh adalah model pembelajaran yang sudah diterapkan dengan kriteria pembelajaran jarak jauh. Seperti dalam pembelajaran yang ada di perguruan tinggi saat ini, Universitas Terbuka menerapkan program pembelajaran jarak jauh dengan sistematika tersebut maka dapat diterapkan dalam perpustakaan jarak jauh dengan menggunakan konsep perpustakaan digital. Model lainnya juga seperti halnya dalam bantuan bimbingan belajar yang tidak lagi menggunakan tempat fisik untuk membeirkan materi dari guru ke muridnya, melainkan dengan bantuan aplikasi belajar yang berjalan pada jalur andorid dan IOS. Konsep-konsep tersebut memberikan dampak kepada pengelola dan pengguna dalam memanfaatkan sistem informasi agar lebih fleksibel dan efisien.

Konsep perpustakaan jarak jauh dapat diartikan sebagai perpustakaan yang mendukung pembelajara jarak jauh yang diselenggarakan oleh lembaga pendidikan. Lembaga pendidikan saat ini sudah mulai merambah pada pendidikan pembelajaran jarak jauh. Pada aplikasi Ipusnas sendiri sudah dapat dikatakan sebagai perpustakaan jarak jauh, dikarenakan mendukung pembelajaran yaitu buku yang ada dalam koleksi database dapat dipinjam dan dibaca ditempat (media pembaca pustaka). Perpustakaan jarak jauh ini adalah bukan seperti perpustakaan digital yang menghadirkan server sebagai pusat perpustakaan, melainkan tetap ada perpustakaan fisik, namun pengguna dapat mengakses perpustakaan sebagai tempat untuk mencari modul, koleksi buku, jurnal dan sebagainya yang berkaitan dengan perpustakaan.

\section{Aplikasi Perpustakaan}

Aplikasi perpustakaan dan penggunaannya di Indonesia dan berbagai belahan dunia. Dibawah ini adalah aplikasi perpustakaan yang digunakan oleh pengelola perpustakaan untuk memduhakan adminsitrasi perpustakaan, pengolahan perpustakaan dan pelayanan perpustakaan kepada pengguna serta menerapkan perpustakaan digital yang masih dapat disebut sebagai sebutan/julukan perpustakaan semi digital atau perpustakaan hybrida.

\section{a. Greenstone Digital Library (GSDL)}

Salah satu aplikasi dari perpustakaan digital adalah Greenstone Digital Library (GSDL). "Greenstone is a suite of software for building and distributing digital library collections. It provides a new way of organizing 
information and publishing it on the Internet or on CD-ROM. Greenstone is produced by the New Zealand Digital Library Project at the University of Waikato, and developed and distributed in cooperation with UNESCO and the Human Info NGO. It is open-source, multilingual software, issued under the terms of the GNU General Public License. Read the Greenstone Factsheet for more information". (http://www.greenstone.org/).

\section{b. Ganesha Digital Library (GDL)}

Ganesha Digital Library (GDL), sama seperti Greenstone yang merupakan perangkat lunak yang ditunjukkan untuk pengelolaan perpustakaan digital. Tafqihan mengemukakan bahwa project GDL merupakan upaya sukarela yang dikembangkan oleh tim Knowledge Management Reseach Group (KMRG) Institut Teknologi Bandung (ITB) dengan tujuan untuk memanfaatkan modal intelektual (intelectual capital) dari civitas akademika ITB yang meliputi artikel, jurnal, tugas akhir, thesis, disertasi, hasil penelitian, expertise directory dan lain-lain (Ristiyono, 2011).

\section{c. Senayan Library Information Management System (SLIMS)}

Senayan Library Information Management System atau sering dikenal dengan sebutan SLIMS. SLIMS yang merupakan suatu Open Source Software (OSS) berbasis web untuk memenuhi kebutuhan otomasi perpustakaan (library automation) skala kecil hingga skala besar dalam konteks Manual Senayan Library Information Management System. Keunggulan SENAYAN lainnya adalah multi-platform, yang artinya bisa berjalan secara mudah di hampir semua Sistem Operasi, Baik itu di Windows dan Linux. Aplikasi perpustakaan Slims ini di Indonesia sudah familiar dan banyak digunakan di kalangan perpustakaan baik itu dimulai dari perpustakaan khusus, perpustakaan pemerintah, perpustakaan sekolah, perpustakaan perguruan tinggi hingga pada perputakaan lainnya. Selain kemudahan, aplikasi ini juga mempunyai tampilan yang user friendly.

\section{B. HASIL DAN PEMBAHASAN}

\section{Aplikasi Ipusnas}

iPusnas adalah salah satu terobosan dari Perpustakaan Nasional (Perpusnas) adalah dengan meluncurkan aplikasi bernama iPusnas. Aplikasi ini bisa digunakan pada beragam perangkat komunikasi kita. Mulai dari smartphone baik android maupun iOS, tablet, dan komputer PC. iPusnas ini merupakan aplikasi perpustakaan digital atau bisa disebut sebagai ePustaka. Apliaksi ini dilengkapi dengan eReader untuk membaca eBook dan fitur sosial media. Artinya fitur tersebut sudah tersedia dan terkoneksi dengan 
aplikasi PDF ebook sebagai fitur utama untuk membaca buku.. Iya seperti namanya perpustakaan, kita bisa meminjam buku yang tersedia di katalog onlinenya.

Cara penggunannya adalah dengan cukup mengunduh aplikasi ini baik di Play Store, Appstore, maupun web resmi iPusnas. Aplikasi ini bisa didapatkan secara gratis. Setelah mengunduh kamu bisa meng-install-nya di perangkat kamu. Setelah itu kamu harus mendaftar anggota, bisa dengan akun email maupun akun Facebook kamu. Nah setelah kamu menjadi anggota kamu bebas meminjam eBook yang tersedia di ePustaka. Keanggotaan di iPusnas ini berlaku selama setahun dan akan diperpanjang secara otomatis. Kalau kamu mau meminjam buku, cukup cari buku yang kamu inginkan lalu pilih dan klik tombol Pinjam. Jika stok habis kamu akan dimasukan dalam daftar antrean. Setelah berhasil meminjam kamu bisa membaca eBook tersebut saat online maupun offline, asalkan kamu sudah mengunduh eBook tersebut. Jangka waktu peminjaman hanya 3 hari, sebelum jangka waktu peminjaman habis kamu harus mengembalikan eBook tersebut, tapi kalau kamu belum selesai membacanya kamu bisa memperpanjang dengan mengisi kembali form peminjaman. Jika kamu lupa tidak mengembalikan dalam jangka waktu 3 hari maka buku tersebut akan hilang secara otomatis dan dikembalikan ke ePustaka iPusnas. Secara umum cara kerja perpustakaan digital ini sama dengan perpustakaan biasa. Bedanya ini semua bisa kamu nikmati dalam genggaman. Lebih praktis kan? Dan kamu juga bisa memberi komentar atau me-review buku yang kamu baca dalam kolom komentar dari setiap eBook. Dan ada fitur yang juga tak kalah menarik, iPusnas ini juga dilengkapi fitur social media. Kamu bisa saling berinteraksi dengan pembaca lain, saling mem-follow, saling merekomendasikan buku yang bagus, dan lain-lain (CNN Indonesia Student, 2016).

Aplikasi iPusnas mendukung pelayanan informasi secara jarak jauh. Dalam konsep perpustakaan jarak jauh maka pelayanan informasi yang disediakan dapat berupa apapun, yang ada dalam perpustakaan tradisional. Pemanfaatan perpustakaan dalam mendukung program layanan informasi perpustakaan dengan metode jarak jauh adalah pada kontribusi penggunaan koleksi digital yang ada dalam aplikasi iPusnas. Jadi dengan pangsa pasar pengguna adalah masyarakat Indonesia, maka aplikasi iPusnas yang berasal dari gen perpustakaan digital berfungsi untuk mencerdaskan masyarakat Indonesia dengan membudayakan membaca di smartphone, tablet atau komputer. Pemanfaatan dalam menumbuhkan minat baca ini adalah menyasar pada seluruh elemna masyaraat, terutama adalah masyarakat yang 
tingal di pelosok pedalaman namun sudah memiliki akses nternet, jika belum memiliki akses internet maka tidak dapat menikmati layanan aplikasi iPusnas ini.

Pemanfaatan lainnya yang hadir dalam aplikasi iPusnas ini adalah mendukung perkembangan teknologi dan mengikuti perkembangan teknologi saat ini. Perpustakaan Nasional berpikiran tidak mau kalah dengan perpustakaan perguruan tinggi atau perpustakaan lainnya yang sudah menerapkan layanan informasi jarak jauh ini. Terlebih lagi Perpusnas adalah lembaga pembina pustaka di Indonesia, seharusnya sudah sewajbnya menyediakan aplikasi yang dapat digunakan oleh masyarakat Indonesia. Program layanan aplikasi iPusnas ini selain menceraskan masyarakat Indonesia juga berfungsi untuk mempromosikan buku-buku yang berkualitas dan layak baca sera menjembatani penulsi buku untuk dapat berkontribusi pada pengabdiannya dalam masyarakat. Ajang promosi yang sering dilakukan adalah bedah buku, iklan melalui pamphlet atau brosur dan melalui iklan di spanduk, namun dengan memanfaatkan program layanan informasi aplikasi iPusnas ini, pengarang dapat lebih mudah mempromosikan hasil karyanya kepad masyarakat. Terlebih lagi dapat dikoneksikan dengan akun sosial media, artinya aplikasi ini sudah terintegrasi dengan sosial media. Fitur share menjadi fitur wajib yang ada pada setiap aplikasi, termasuk pada aplikasi iPusnas ini.

\section{Desain dan Tampilan Aplikasi}

Desain dan tampilan aplikasi secara penghilatan orang awam pun sangat mudah untuk dikenali dan digunakan. Artinya aplikasi iPusnas ini dalam versi windows yang berjalan di perangkat komputer dapat digunakan dengan mudah. Perpaduan warna juga menjadi daya tarik tersendiri. Ditambah juga pengatuan masuk ke aplikasi dengan akun facebook dan email menambah mudah penguna untuk $\log$ in dan mendaftar menjadi anggota aplikasi iPusnas ini (gambar 1). 
14| Verry Mardiyanto: Opini dan Analisis Program ...

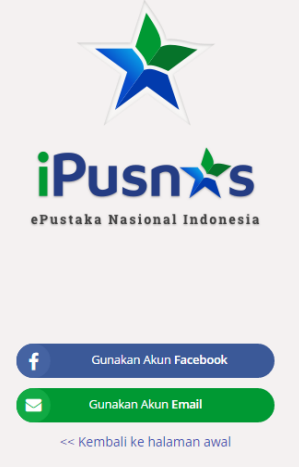

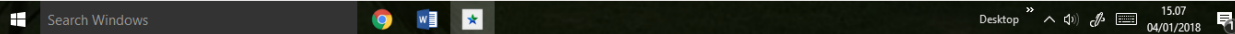

Gambar 1. Area Log In dan Fitur Daftar Menjadi Anggota

Pada gambar 2 adalah fitur beranda. Fitur ini adalah tampilan utama ketika menggunakan aplikasi iPusnas. Setelah log ini, Anda dialihkan ke beranda. Di beranda ini, Anda disuguhkan informasi mengenai buku-buku yang di baca oleh pengunjung dan anggota yang terdaftar di iPusnas.

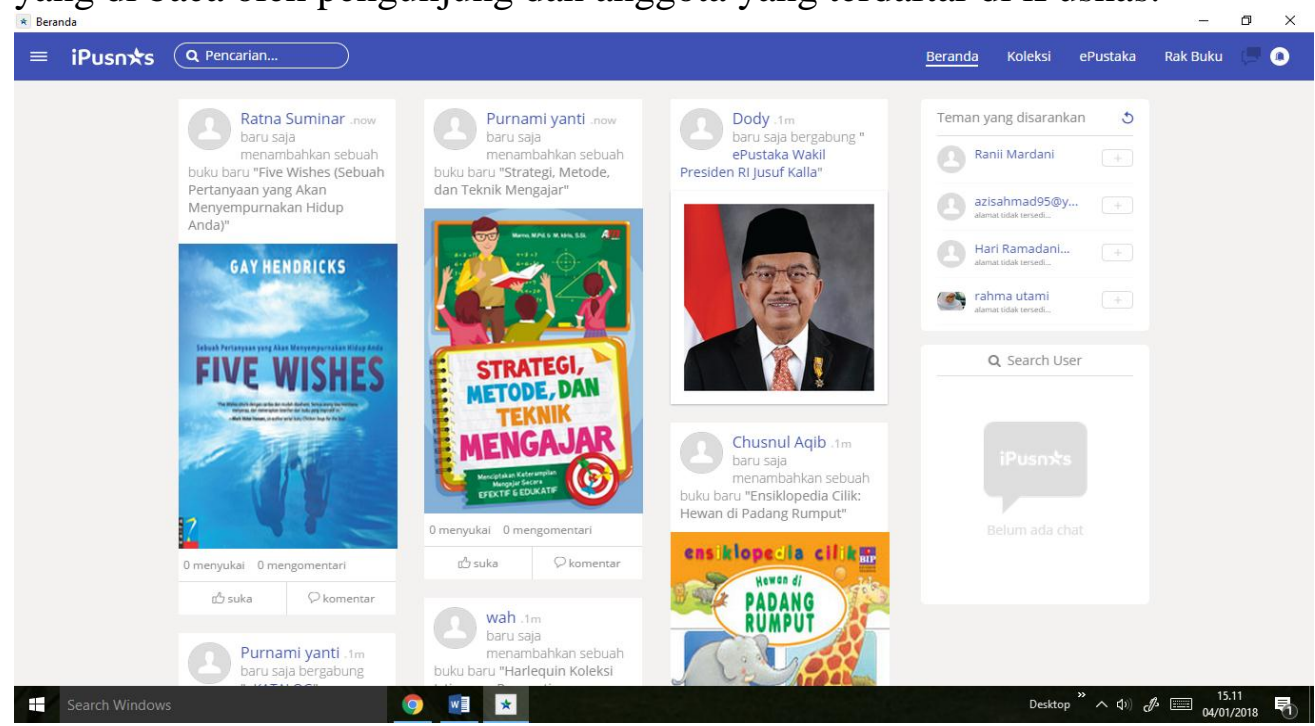

Gambar 2. Fitur Beranda

Pada gambar 3 adalah fitur koleksi. Fitur koleksi ini menampilkan buku-buku yang sedang trends dan buku baru. Buku di area koleksi ini dapat 
berupa buku umum, buku pengetahuan, buku fiksi dan buku yang seraing Anda cari di fitur pencarian.

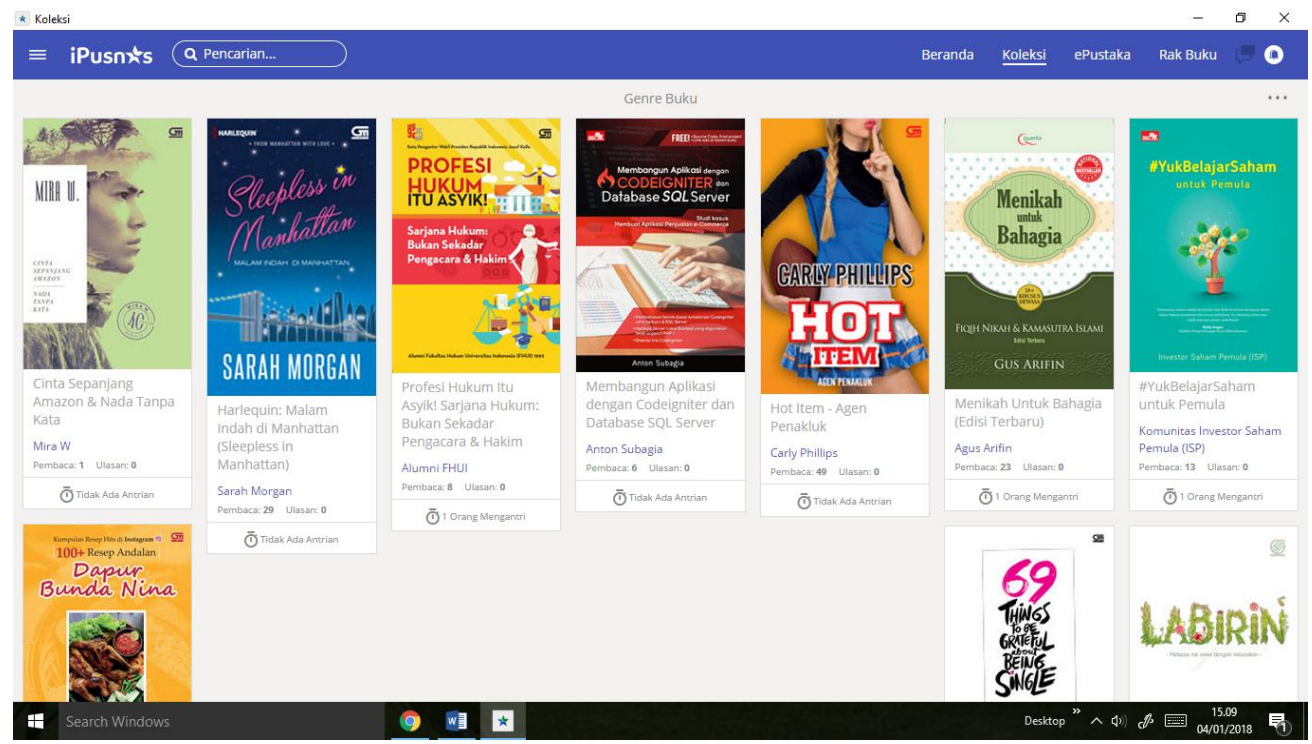

Gambar 3. Fitur Koleksi

Fitur ePustaka pada gambar 4 ini menampilkan tokoh-tokoh pejabat Indonesia yang ada dalam hubungannya dengan Perpustakaan Nasional. Selain itu juga ditampilkan popular, ekatalog dan Indonesia one search sebagai akun yang dikelola oleh Perpustakaan Nasional.

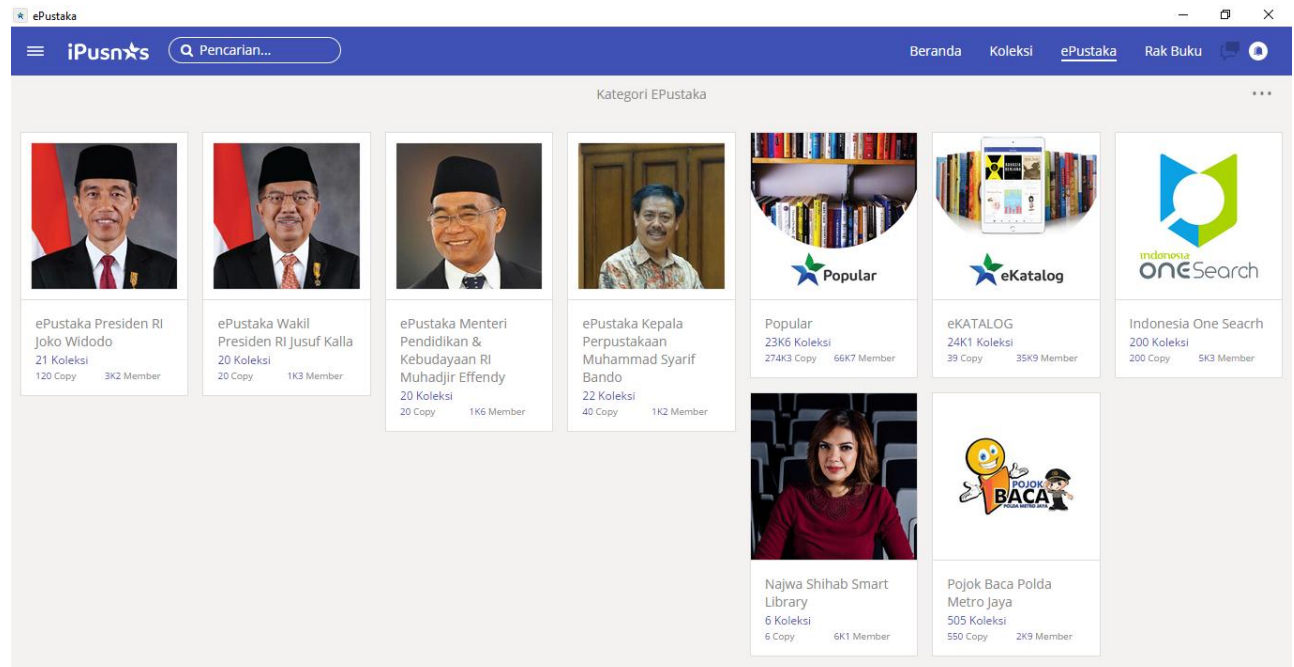


Fitur rak buku pada gambar 5 di bawah ini adalah menu dashboard akun di iPusnas. Anggota dapat melihat menu pinjaman yang sedang di pinjam, kemudian menu antrian untuk buku yang sedang di pinjam orang lain kemudian jika Anda mengklik antrian maka buku tersebut akan Ada di akun Anda setelah pengguna yang meminjam buku tersebut mengembalikan atau otomatis kembali. Selanjutnya adalah menu riwayat, menu ni adalah melihat history dari buku-buku yang sudah ada pinjam. Di dalam menu riwyat ni, Anda dapat meminjam kembali buku tersebut, jika buku tersebut terdapa ketersediaan untuk dipinjam.

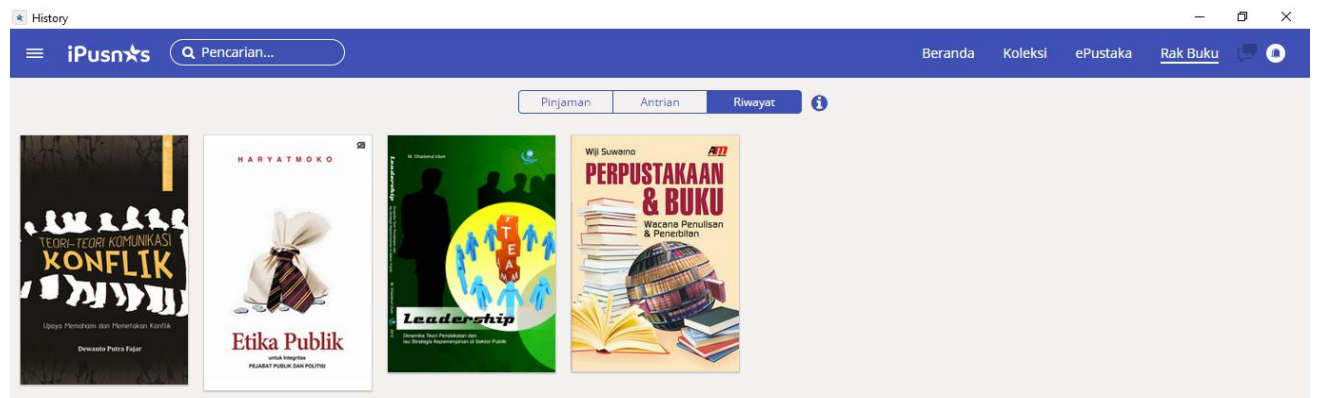

\section{Gambar 5. Fitur Rak Buku}

\section{Proses Layanan Informasi di Aplikasi Ipusnas}

Proses layanan informasi yang ada di aplikasi iPusnas ini adalah sama ketika Anda pernah berkunjung ke perpustakaan tradisional atau perpustakaan hibrida. Dalam aplikasi ini Anda diharuskan mendaftar untuk dapat menikmati layanan informasi yang ada didalamnya. Cukup sediakan waktu 60 detik maka Anda sudah dapat menjadi anggota dari aplikasi iPusnas ini. Setelah Anda terdaftar menjadi anggota, maka Anda akan melakukan pencarian informasi pada kata kunci. Dalam gambar 6 di bawah ini, dituliskan kata "perpustakaan digital" maka akan menemukan koleksi buku septura perpustakaan. Anda tinggal memilih yang paling cocok dan sesuai dengan koleksi buku yang Anda butuhkan. 


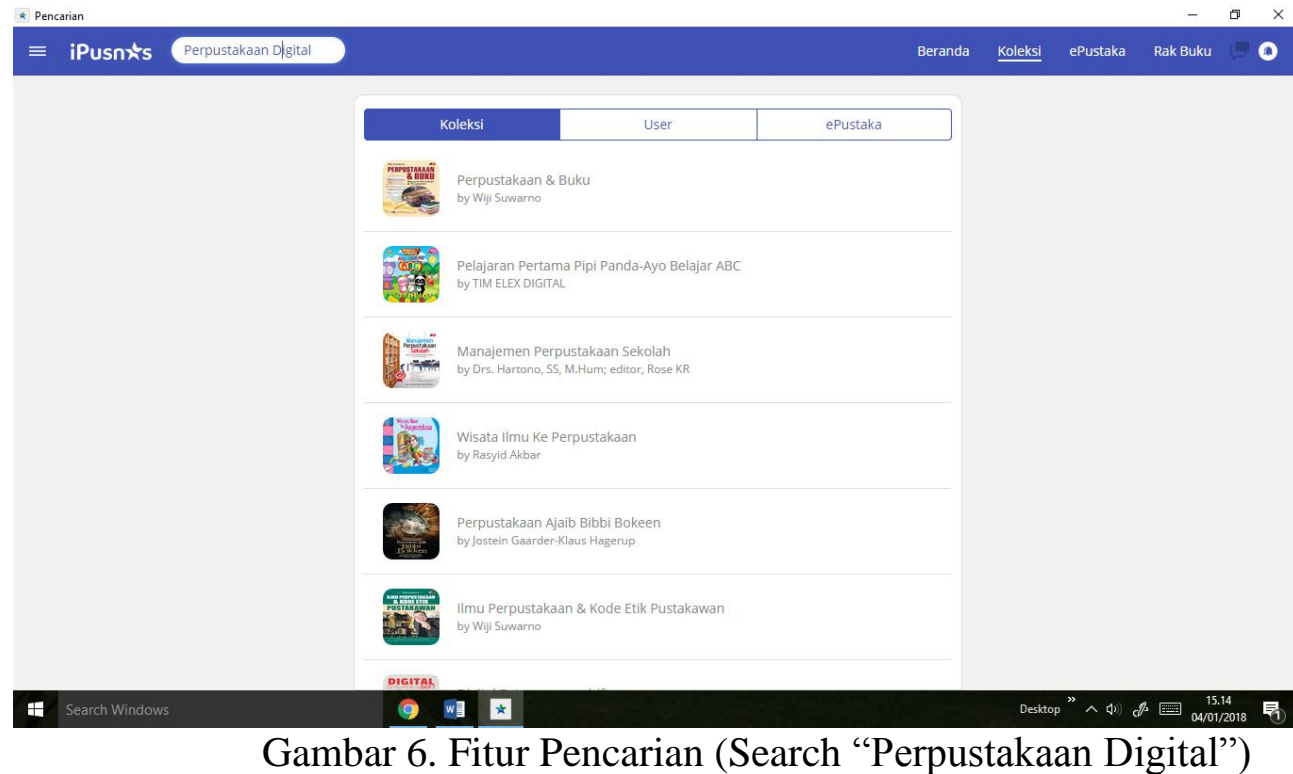

Bagaimana cara meminjam buku dan emudian dapat membaca buku yang anda inginkan. Gambar 7 adalah contoh buku yang akan di pinjam. Klik pinjam buku, kemudian akan muncul tab konfirmasi untuk meminjam buku, Pilih "Ya" untuk melanjutkan dan Anda sudah dapat membaca buku. Tab konfirmasi dapat dilihat pada gambar 8 .

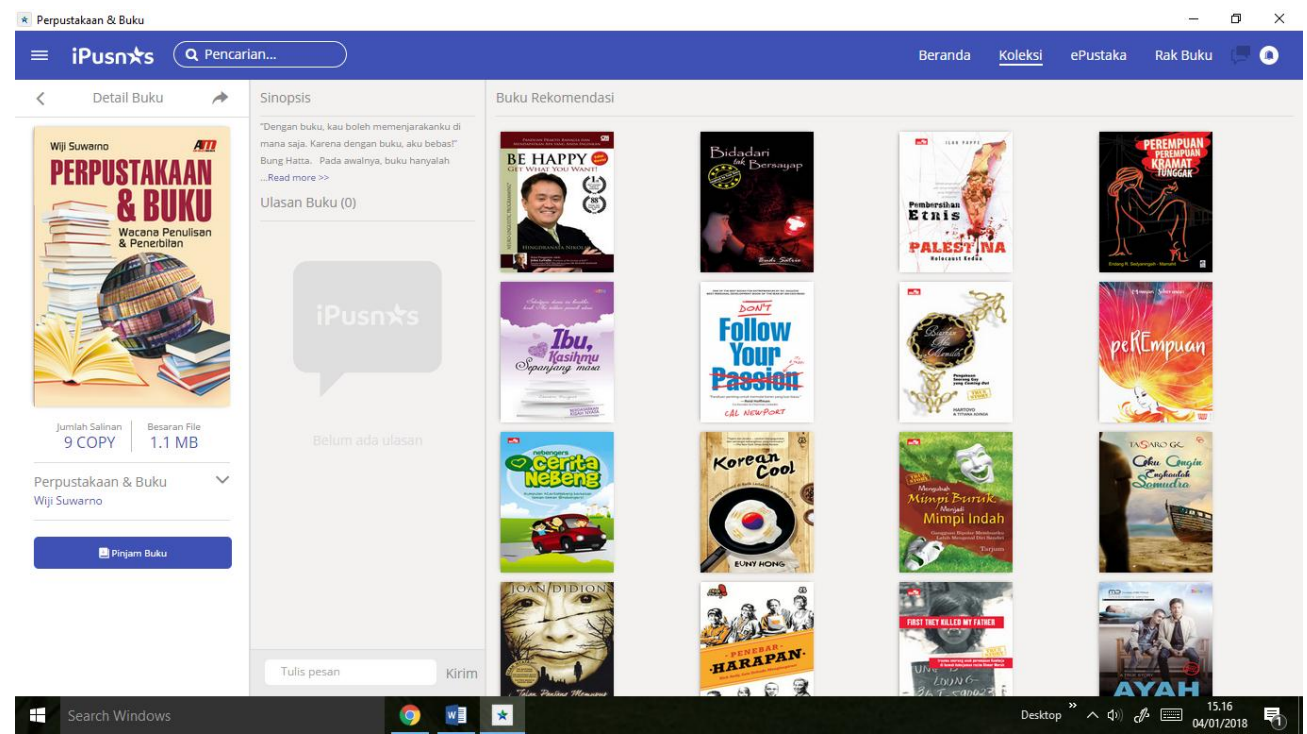

Gambar 7. Pinjam Buku 
18| Verry Mardiyanto: Opini dan Analisis Program ...

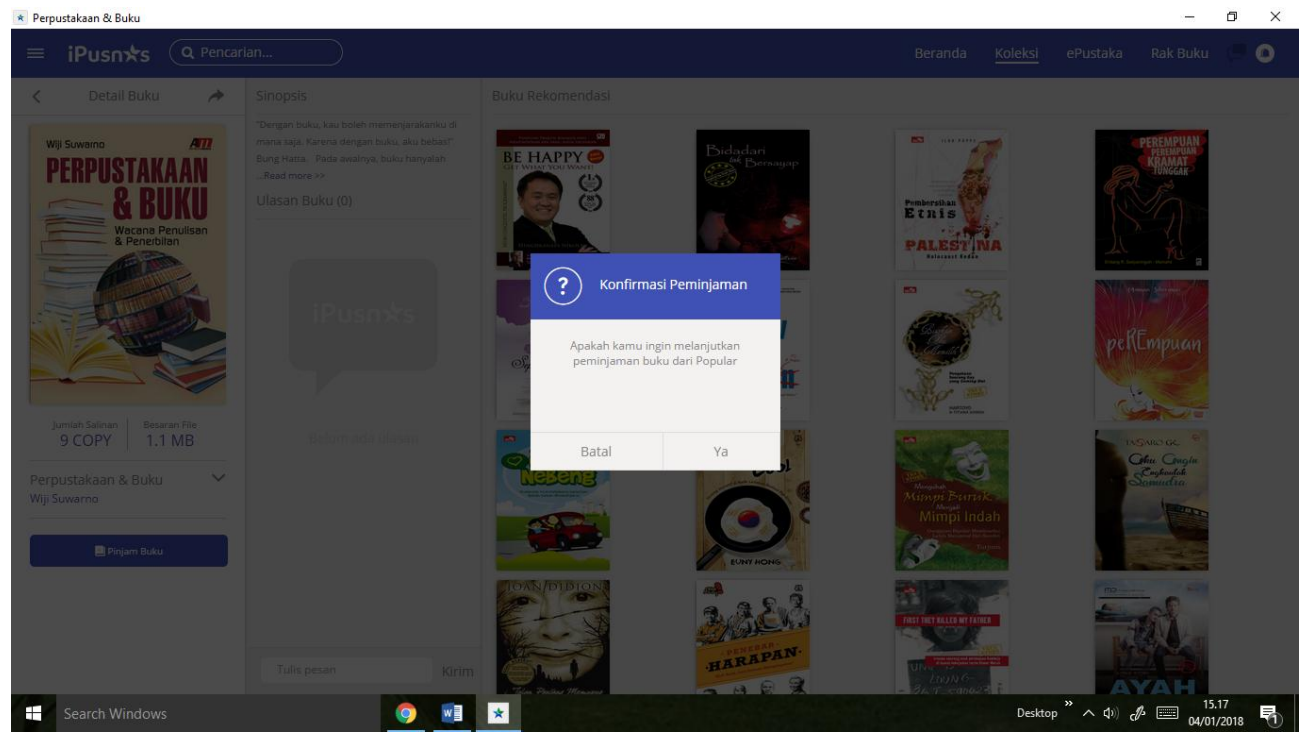

Gambar 8. Konfirmasi Pinjam Buku

Setelah Anda mengklik Yam aka Anda dialihkan ke bagian PDf sebagai media untuk membaca buku tersebut. Gambar 9 menunjukkan menu dashboard anggota iPusnas. Menu ini berfungsi untuk melihat buku yang Anda pinjam, panel antrian dan riwayat buku yang pernah Anda pinjam.

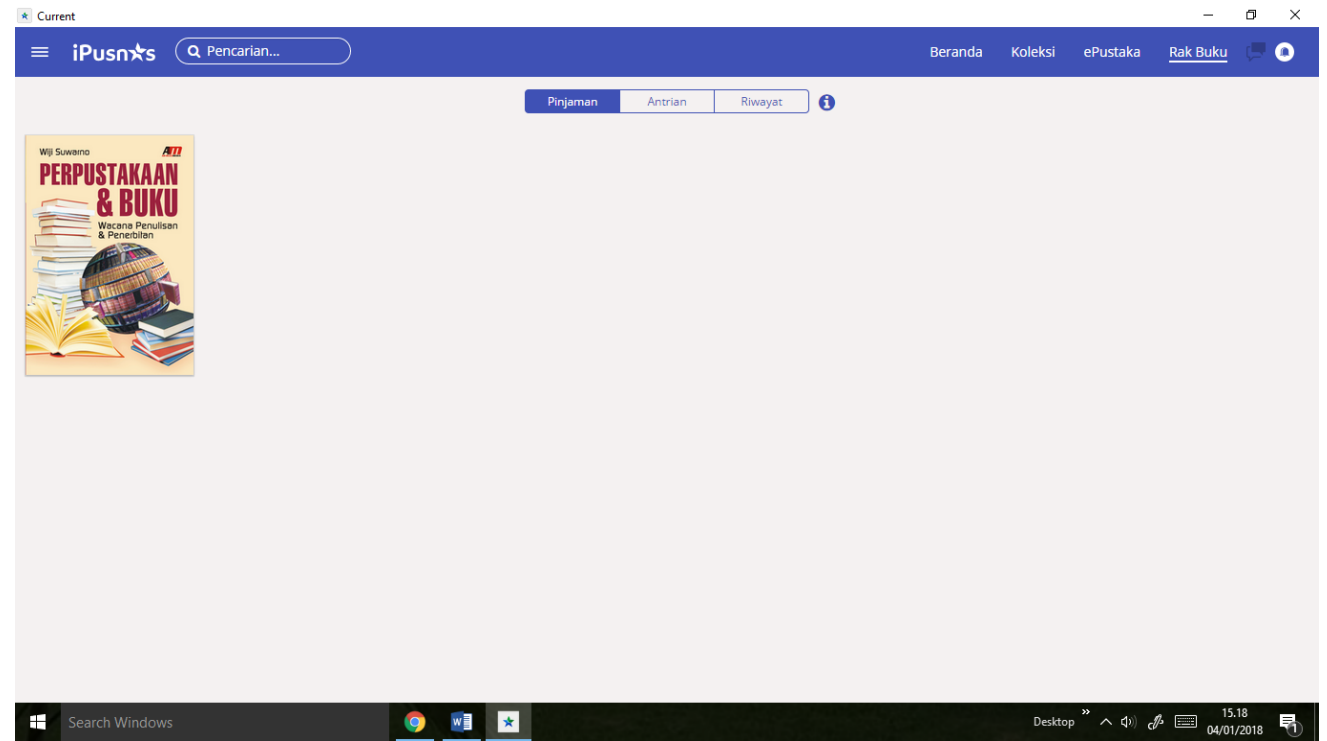

Gambar 9. Area Pinjaman

Gambar 10 adalah menu yang menampilkan buku yang sudah Anda pinjam dan hendak Anda baca. Aplikasi iPusnas ini menggunakan struktur 
ebook berbentuk pdf. Selain mudah dibaca, file pdf ini juga familiar digunakan oleh masyarakat umum.

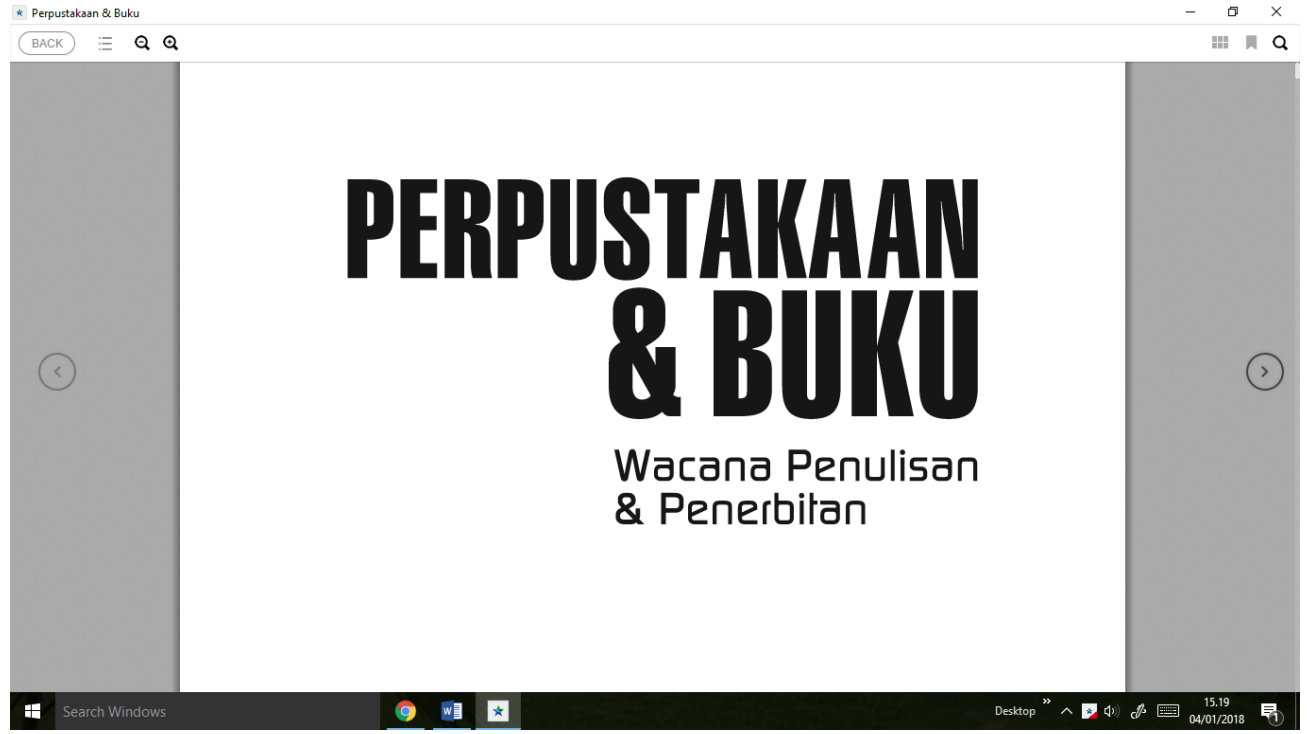

Gambar 10. Buku PDF

Peraturan yang umum ada di aplikasi iPusnas ini adalah pada kategori peminjaman dengan maksimal 3 buku per hari. Untuk pengembalian otomatis sendiri sesuai waktu hari pinjam atau engan mengklik fitur pengembalian. Untuk secara otomatis maka jika pengguna tidak mempergunakan koleksi tersebut di hari esok akan secara otomatis koleksi tersebut dikembalikan dan berpindah dari area pinjaman ke area riwayat. Pada area riwayat, pengguna dapat meminjam lagi koleksi tersebut.

\section{Kelebihan dan Kekurangan}

Setelah menggunakan dan menganalisis aplikasi iPusnas ini dari sudut pandang pengguna aplikasi, maka dapat dideskripsikan kelebihan dan kekurangan yang ada, yaitu:

Kelebihan:

a. Aplikasi ini dapat berjalan pada sistem operasi windows, ios iphone dan android.

b. Desain dan cara penggunaan mudah digunakan.

c. Aplikasi gratis dapat diunduh oleh siapapun.

d. Koleksi buku bervariasi dan terbilang banyak.

e. Jika Anda lupa mengembalikan, maka secara otomatis buku yang Anda pinjam akan kembali dengan sendirinya. 
Kekurangan:

a. Aplikasi lumayan berat untuk versi windows, jadi siapkan internet yang cepat dan komputer Anda dalam keadaan performa baik.

b. Ada beberapa buku yang jumlah koleksi 0, jadi tidak dapat dipinjam dan dibaca.

c. Hanya membatasi 3 koleksi buku perhari, jadi jika Anda sudah membaca 3 buku dalam sehari maka Anda tidak data meminjam dan melihat buku lagi, sebelum Anda mengembalikan buku tersebut atau dikembalikan secara otomatis.

d. Untuk judul buku tertentu misalkan perpustakaan dan kearsipan, jumlahnya sedikit.

Pada bagian menu ebook pdf, buku ini tidak dpat di copy sehingga harus dibaca dan dipahami agar Anda tidak melanggar hak cipta dari bukubuku tersebut.

\section{KESIMPULAN}

Tulisan ini menyimpulkan bahwa program layanan informasi di perpustakaan dengan metode jarak jauh (studi kasus layanan informasi menggunakan aplikasi imobile ipusnas) dapat dikatakan sebagai perpustakaan digital yang menggunakan konsep perpustakaan jarak jauh. Perpustakaan jarak jauh ini membuat pengguna masyarakat menjadi lebih mudah dalam memanfaatkan layanan perpustakaan. Seperti layaan infrmasi yang berdampak pada peningkatan minat baca, layanan informasi yang berdampak pada meningkatnya pengetahuan dan pendidikan yang diukur dalam indeks pembangunan manusia. Aplikasi iPusnas ini juga mampu memberikan inovasi yang hadir dalam kategori aplikasi yang dimiliki oleh pemerintah pusat, dengan hadirnya aplikasi ini bertanda bahwa perpustakaan juga memiliki daya saing kepada perpustakaan-perpustakaan swasta yang saat ini sudah mendahului layanan informasi yang mereka miliki berbasiskan aplikasi mobile.

Pemanfaatan yang ada adalah pada penguatan informasi yang terkini. Aplikasi ini membantu penyebaran informasi dari pembuat karya dalam kategori koleksi buku kepada masyarakat secara langsung. Teknologi pada aplikasi iPusnas berfungsi untuk memberkan layanan pada masyarakat pelosok yang ada di daerah-daerah untuk dapat menikmati koleksi buku yang ada di Perpustakaan Nasional, tanpa perlu pergi ke Perpustakaan Nasional di Jakarta. 
Proses layanan informasi yang ada di aplikasi iPusnas dapat dikatakan mudah dan simpel, sehingga siapapun orang yang sudah mengerti teknologi informasi akan dapat menggunakannya. Selain itu juga, aplikasi ini mengedepankan desain dan tampilan yang inovatif dengan gaya kekinan, sehingga tidak membosankan dan tampil segar seperti zaman sekarang ini. Proses layanan juga terbilang mudah, ketika akan meminjam buku dan membacanya cukup dengan beberapa tahapan maka sudah dapat menikmati layanan peminjaman koleksi buku trsebut.

Kelebihan dan kekurangan diaplikasi iPusnas memberikan peluang utnuk menggunakan aplikasi ini secara menyeuruh dan dipergunakan bagi masyaraat sebagai solusi atas perpustakaan umum, antara pusat dan daerah yang selama ini belum berkonsentrasi pada pengembangan perpustakaan secara digital. Kekurangan menjadi bagian yang harus diperbaiki ketika kekurangan tersebut sudah diatasi maka pengguna dalam kategori anggota aplikasi iPusnas ini akan semakin memberikan respons positif. Selain itu juga pengguna akan menambah frekuensi penggunaan aplikasi ini untuk mengatasi permasalahsn tentang penambahan kapasitas pengetahuannya dan memecahkan masalah lainnya yang berhubungan dengan sumber informasi yang ada di perpustakaan digital.

Saran dalam mempergunakan aplikasi iPusnas ini adalah dengan menggunakan perangkat komputer atau smartphone yang mempunyai spesifikasi tinggi maka akan dengan mudah melakukan penelusuran dan mempergunakan aplikasi ini tanpa hambatan. Ditambah juga dengan jaringan internet yang stabil. Selain itu juga dalam menggunakan aplikasi ini harus dengan sabar dan melihat koleksi lainya untuk dapat memaksimalkan pinjaman 3 buku dalam sehari. Saran bagi masyarakat adalah dengan menggunakan aplikasi iPusnas ini maka Anda dapat membantu mengembangkan aplikasi perpustakaan digital milik Perpustakaan Nasional ke arah yang lebih baik lagi. Hal yang dapat dilakukan adalah dapat menuliskan saran dan kritik pada fitur yang tersedia di aplikasi iPusnas.

\section{DAFTAR RUJUKAN}

Ardian Fanani. (2017). Desa di Kaki Gunung Ijen ini Dilengkapi Perpustakaan Digital. Diterima dari https://news.detik.com/jawatimur/3664470/desa-di-kaki-gunungijen-ini-dilengkapi-perpustakaan-digital 
Arlinah I.R. (2017). Layanan Jasa Informasi Perpustakaan. Diterima dari faculty.petra.ac.id/arlinah/perpustakaan/layanan/layanan_informa si.pdf

Moleong, Lexy J. (2008). Metodologi Penelitian Kualitatif. Bandung: Remaja Rosda Karya.

Pandu Ristiyono. (2018). Layanan Bahan Ajar (Modul) Online di Perpustakaan Universitas Terbuka : Peranan Perpustakaan dalam Pembelajaran di Universitas Terbuka. (Majalah Visi Pustaka, Vol.13 No.2 - Agustus 2011). Diterima dari http://old.perpusnas.go.id/MajalahOnlineAdd.aspx?id=163

Pendit, Putu Laxman. (2008). Perpustakaan Digital dari A - Z. Jakarta: Cita Karyakarsa Mandiri.

-----------. (2009). Perpustakaan Digital: Kesinambungan \& Dinamika. Jakarta: Cita Karyakarsa Mandiri.

Sri Noviyanti. (2018). Perpustakaan Digital, Rujukan Khusus untuk Mahasiswa "Online Learning. Diterima dari http://edukasi.kompas.com/read/2015/05/05/07300021/Perpustak aan.Digital.RujukaR.Khusus.untuk.Mahasiswa.Online.Learning

Tafqihan, Zuhdy. (2010). Membandingkan Greenstone Digital Library (GSDL) dan Ganesha Digital Library (GDL). Jurnal Kajian Informasi dan Perpustakaan, 2(1): 105-114.

Verry Lyuzz. (2018, Januari 04). Perpustakaan Digital dan Perkembangannya "Paper Tentang Perkembangan Perpustakaan Digital di Internasional dan Indonesia Dari Tahun ke Tahun [Blog post]. Diterima dari http://arsipilmu04936.blogspot.co.id/search?q=perpustakaan+digi tal

Aplikasi iPusnas versi Windows. Perpustakaan Nasional Republik Indonesia. 2018. 